\title{
Environmental Influences on Growth and Reproduction of Invasive Commelina benghalensis
}

\author{
Mandeep K. Riar, ${ }^{1}$ Danesha S. Carley, ${ }^{1}$ Chenxi Zhang, ${ }^{1}$ Michelle S. Schroeder-Moreno, \\ David L. Jordan, ${ }^{1}$ Theodore M. Webster, ${ }^{2}$ and Thomas W. Rufty ${ }^{1}$ \\ ${ }^{1}$ Department of Crop Science, North Carolina State University, Raleigh, NC 27695, USA \\ ${ }^{2}$ Crop Protection and Management Research Unit, USDA-ARS, Tifton, GA 31793, USA
}

Correspondence should be addressed to David L. Jordan; david_jordan@ncsu.edu

Received 28 June 2015; Accepted 14 January 2016

Academic Editor: Rodomiro Ortiz

Copyright (C) 2016 Mandeep K. Riar et al. This is an open access article distributed under the Creative Commons Attribution License, which permits unrestricted use, distribution, and reproduction in any medium, provided the original work is properly cited.

\begin{abstract}
Commelina benghalensis (Benghal dayflower) is a noxious weed that is invading agricultural systems in the southeastern United States. We investigated the influences of nutrition, light, and photoperiod on growth and reproductive output of C. benghalensis. In the first experimental series, plants were grown under high or low soil nutrition combined with either full light or simulated shade. Lowered nutrition strongly inhibited vegetative growth and aboveground spathe production. Similar but smaller effects were exerted by a $50 \%$ reduction in light, simulating conditions within a developing canopy. In the second series of experiments, $C$. benghalensis plants were exposed to different photoperiod conditions that produced short- and long-day plants growing in similar photosynthetic periods. A short-day photoperiod decreased time to flowering by several days and led to a 40 to $60 \%$ reduction in vegetative growth, but reproduction above and below ground was unchanged. Collectively, the results indicate that (1) fertility management in highly weathered soils may strongly constrain competitiveness of C. benghalensis; (2) shorter photoperiods will limit vegetative competitiveness later in the growing seasons of most crops; and (3) the high degree of reproductive plasticity and output possessed by $C$. benghalensis will likely cause continual persistence problems in agricultural fields.
\end{abstract}

\section{Introduction}

Commelina benghalensis $\mathrm{L}$. is among the world's worst weeds in agricultural systems, with infestations occurring in 25 crops in 29 countries. In the US, it became established in Florida in the early 1930s [1] and is now moving northward. The prevalence in Georgia has led to challenges with Commelina benghalensis control in cotton (Gossypium hirsutum L.) and peanut (Arachis hypogaea L.) production [2], as infestations have commonly caused $60 \%$ to $100 \%$ yield reductions $[3,4]$. And there are observations indicating that C. benghalensis may be spreading further northward as far as North Carolina [5].

A key to C. benghalensis invasiveness is its reproductive flexibility. In its native geographical areas, that is, tropical Asia, Africa, and the Pacific Islands, C. benghalensis grows as a perennial, but it can survive as an annual in temperate regions [6]. It is fast growing and a prolific seed producer [7]. Both aerial and subterranean seeds are produced in dimorphic flowers [8], and seeds have variable dormancy and germination characteristics $[9,10]$. Furthermore, $C$. benghalensis has the ability to regenerate from stem fragments [11]. These characteristics, plus a high degree of tolerance to glyphosate [12], make C. benghalensis exceptionally difficult to control in agronomic systems when it becomes established.

We are investigating environmental effects on C. Benghalensis growth and development. The purpose is to gain insights into factors that influence its competitiveness and persistence, which are keys for assessment of the risk of invasions and formation of long-term control strategies. In recent experiments, it was found that seeds of $C$. benghalensis can persist in soil for up to four years in areas extending from Florida and Georgia to North Carolina [13]. This implied that the management programs must prevent seed 
production for that period of time to effectively reduce seed banks. In further agroecological studies, it was found that control of $C$. benghalensis will be especially problematic in sustainable farming systems not using herbicides [14]. The viability of $C$. benghalensis seed acquired during grazing or consumption of fresh hay is not reduced during animal digestion and generation of manure, so there is no restraint on seed dispersal. Also, vegetative regeneration was near its maximum in the temperature range typical in summers in the southeastern US, severely limiting the potential effectiveness of cultivation.

In the study described in this paper, we examine $C$. benghalensis responses to several environmental variables that can be related to prediction of field behavior. Two of the variables examined, light and photoperiod, required that experiments be conducted in controlled-environment growth chambers. Specific questions were being addressed. One was "how are growth and development of $C$. benghalensis altered by changes in nutrition and light?” Crops are fertilized at different levels, so the magnitude of the fertility response would help predict cropping systems where $C$. benghalensis would be more or less aggressive. Exposure to low light will reveal the extent that growth and development might be expected in crop understories or small gaps in crop populations. Another question was "how is C. benghalensis affected by altered photoperiod?" With current warming patterns $[15,16]$, cropping seasons can be extended, unless a counterbalancing effect is exerted by shorter day lengths. To assess responses in a worst case scenario, the environmental treatments were imposed under relatively high temperatures of $30-35^{\circ} \mathrm{C}$, a temperature range common in the southeastern states in the US, when crop interference by weeds most often occurs, and a range where $C$. benghalensis exists [17].

\section{Materials and Methods}

2.1. Nutrition and Shade. Experiments were conducted in walk-in environmental chambers at the Southeastern Plant Environment Laboratory, Raleigh, NC. Large aerial seeds of C. benghalensis were germinated in $6 \mathrm{~L}$ plastic pots $(25 \mathrm{~cm}$ diameter) containing Norfolk sandy loam soil (kaolinitic, thermic Typic Kandiudults, bulk density $1.2 \mathrm{~g} \mathrm{~cm}^{-3}$ and $\mathrm{pH}$ 6.1). Prior to sowing, seeds were disinfected by soaking in $5 \%$ bleach solution $(0.25 \% \mathrm{NaOCl})$ for $5 \mathrm{~min}$, rinsed with water, and then scarified with a blade to break physical dormancy and enhance germination [18]. Seeds were germinated at a constant day/night temperature of $30 / 30^{\circ} \mathrm{C}$, with a $9 \mathrm{~h}$ photoperiod. Treatments were imposed just after seedlings were thinned to two per pot at the one-leaf stage (approximately 10 days after seeding). The treatments examined $C$. benghalensis responses at two nutrient levels and under two light intensities. Lighting was provided at either full $\left(600 \mu \mathrm{mol} \mathrm{m}{ }^{-2} \mathrm{~s}^{-1}\right)$ or reduced $\left(324 \mu \mathrm{mol} \mathrm{m}^{-2} \mathrm{~s}^{-1}\right)$ PPFD, provided by a combination of incandescent and fluorescent lamps. Reduced lighting was achieved by covering the area with a shade cloth. PPFD was measured with a LI-191 Line Quantum Sensor (LI-COR Biosciences, Lincoln, $\mathrm{NE}$ ). The daily light and dark periods were maintained from 08:00 to $17: 00 \mathrm{~h}$ and 17:00 to $08: 00 \mathrm{~h}$, respectively. The aerial temperature was held constant at $30^{\circ} \mathrm{C}$. Soil temperatures were monitored continuously at a $2 \mathrm{~cm}$ depth in the pots using temperature probes (WatchDog A-Series Data Loggers, Spectrum Technologies). Soil temperatures were within a $\pm 3^{\circ} \mathrm{C}$ range of aerial temperatures under all treatments.

The experimental design was a split-plot with light intensity as the main plot and nutrient level as the subplot. Each light treatment was subdivided into two nutrient treatments. Pots with high nutrition received $200 \mathrm{~mL}$ of complete Hoagland nutrient solution [19] every day, and pots with low nutrient level received $200 \mathrm{~mL}$ of the same solution once a week, with deionized water added on the other days. Each pot was flushed with deionised water prior to nutrient additions to minimize residual nutrient accumulation. Three pots from each treatment combination were randomly selected and harvested at 14, 28, 35, 42, 49, and $56 \mathrm{~d}$ after treatments started. At harvests, plants were separated into aerial and subterranean tissues. The tissues were further separated into aerial vegetative (shoots and leaves), aerial reproductive (aerial spathes), subterranean vegetative (roots), and subterranean reproductive (rhizomes and spathes). All tissues were dried to a constant mass at $60^{\circ} \mathrm{C}$ in a drying oven and weighed afterwards. To avoid seed dissemination, aerial fruits were collected prior to dehiscence throughout the treatment period. Plant height, number of leaves, and leaf area were also measured at time of harvest. A standard Li-Cor model LI-3100C Area Meter (LI-COR Biosciences, Lincoln, NE) was used to measure leaf area per plant. There were 3 replications for each treatment and the experiment was conducted twice. Data were analyzed using the GLIMMIX procedure in SAS version 9.3 (SAS Institute, Inc., Cary, NC). Mean separation was performed using Tukey's honest significant difference (HSD) at $\alpha=0.05$.

2.2. Photoperiod. Photoperiod experiments also were conducted in growth chambers at the Southeastern Plant Environment Laboratory. Seed treatment, germination, seedling establishment conditions, and soil were the same as described previously. In this circumstance, plants were exposed to five temperature-photoperiod regimes established in five reachin environmental chambers. Twelve pots were kept in each chamber.

The five day/night temperature-photoperiod regimes included $30 / 22^{\circ} \mathrm{C}$ with long-day $(12 \mathrm{~h}), 30 / 22^{\circ} \mathrm{C}$ with shortday $(9 \mathrm{~h}), 35 / 28^{\circ} \mathrm{C}$ with long-day, $35 / 28^{\circ} \mathrm{C}$ with short-day, and a constant day/night temperature at $30^{\circ} \mathrm{C}$ with shortday. Each growth chamber was programmed with one unique combination of day/night temperature and photoperiod. In the short-day regime, day and night periods were maintained from $08: 00$ to $17: 00 \mathrm{~h}$ and from 17:00 to $08: 00 \mathrm{~h}$, respectively. Illumination during day hours was provided by a combination of incandescent and fluorescent lamps with a PPFD of $600 \mu \mathrm{mol} \mathrm{m} \mathrm{m}^{-2} \mathrm{~s}^{-1}$. The long-day regime was achieved by imposing the $3 \mathrm{~h}$ night interruption with incandescent lighting (from 00:00 to 03:00 $\mathrm{h}$ by incandescent lamps generating a nonphotosynthetic PPFD of $40 \mu \mathrm{mol} \mathrm{m}^{-2} \mathrm{~s}^{-1}$ ). By disrupting continuous night hours, the night interruption leads to similar flowering transition effects as those occurring with actual long-day hours [20]. But, with similar photosynthetic 


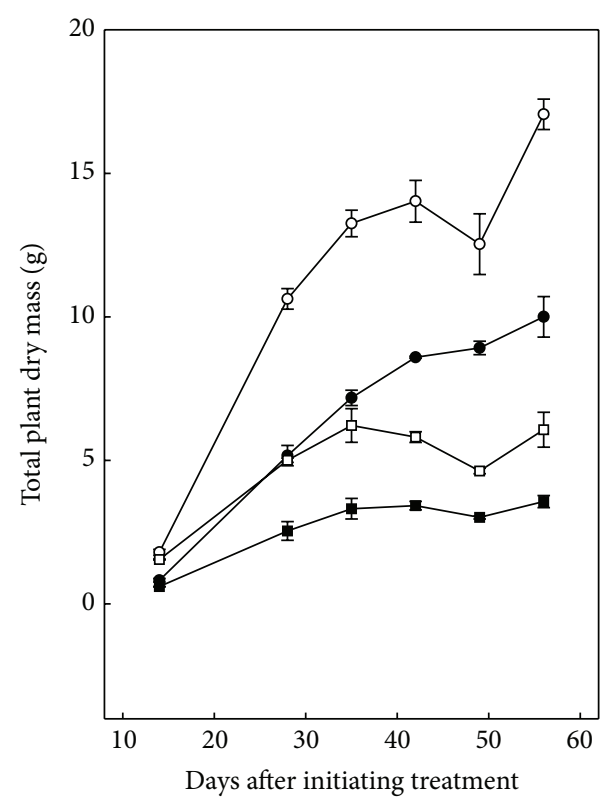

- High nutrition, full light

- High nutrition, reduced light

口 Low nutrition, full light

- Low nutrition, reduced light

FIGURE 1: Effects of nutrition level and light intensity on total dry mass of $C$. benghalensis. Data points are means of six replicates, and bars indicate standard errors of the mean.

period lengths, the conditions allow the physiological effects exerted by vegetative/reproductive shifts to be evaluated alone. The night interruption technique has been used in many experiments over the years in controlled environment to suppress flowering of crop plants [19].

Plants were watered twice daily with $150 \mathrm{~mL}$ deionized water and once every other day with $200 \mathrm{~mL}$ complete Hoagland nutrient solution [19]. The plants thus were growing under high nutrition similar to that in the previous nutrition experiments. Three pots from each chamber were randomly selected and harvested at $14,28,42$, and $56 \mathrm{~d}$ after treatment. Tissues were separated and processed as described previously. The experiment was repeated twice and data were combined and analyzed using the GLM procedure in SAS 9.3. (SAS Institute, Inc., Cary, NC).

\section{Results and Discussion}

3.1. Responses to Nutrition and Reduced Light. C. benghalensis whole-plant mass accumulation increased greatly with a higher level of nutrition (Figure 1), especially under full light. Increased growth included increases in root mass and plant height (Figures 2(a) and 2(b)). Impacts on leaf morphology were particularly pronounced, as the number of leaves and the leaf area per plant were considerably greater in plants receiving higher nutrition, regardless of light intensity (Figures 2(c) and 2(d)). This response is typical for fastgrowing plants under high nutrition, where shoot growth is often stimulated more than root growth, resulting in an increase in the shoot to root growth ratio [21, 22].
Reproduction of $C$. benghalensis was also greater at high nutrition. Time to flowering was not changed (data not shown), but the number of aerial spathes was constantly greater in plants grown in high nutrition after the first sampling date, and by the end of the 56 day experiment, it was 3 times greater than that with low nutrition (Table 1). In contrast, the statistical analyses indicated that production of subterranean spathes varied little between the two nutrition levels.

The fertility responses are especially relevant for field responses in the southeastern US because soils are highly weathered with inherently low nutrition [23], and fertility requirements can be very different among cropping systems. Based on studies done with a number of higher plant species, it has been proposed that weed invasiveness is strongly linked with increased growth rates under improved resource conditions, but that invasive species may not outperform native or noninvasive species when resources are limited [24-27]. The strong response of C. benghalensis to increased nutrition in our experiments suggests that it would be much more aggressive in cropping systems with high rates of fertilization like those with corn (130-170 kg N/ha) and much less so in crops grown with lower fertilizer additions like $\mathrm{N}_{2}$ fixing soybean that often receives low amounts of fertilizer $(<33 \mathrm{~kg} \mathrm{~N} / \mathrm{ha})$ if any at all.

There are circumstances where weed species might acquire nitrogen from alternative sources. Experiments using ${ }^{15} \mathrm{~N}$ natural abundance, for example, found that weeds could obtain large amounts of nitrogen transferred from $\mathrm{N}_{2}$-fixing soybean [28]. However, because transfer occurred through and was dependent on soil-borne mycorrhizae, this type of alternative nitrogen acquisition would not be available to $C$. benghalensis. Our recent analyses have indicated that it is not a mycorrhizal host species (Riar, unpublished observation). Therefore, growth and competitiveness of $C$. benghalensis would primarily be influenced by fertilization in the crop system.

Shading was used in this study to examine C. benghalensis growth and reproductive output under reduced light, in an attempt to simulate conditions that exist when growing concurrently with a developing leaf canopy. Shading greatly reduced total biomass of $C$. benghalensis (Figure 1) when plants received the same nutrition level. Similarly, root mass was consistently less in shaded plants, especially under the high nutrition treatment (Figure 2(a)). Low light conditions tended to increase plant height, but differences were not statistically significant (Figure 2(b)). Shading had little effect on total leaf number and leaf area per plant (Figures 2(c) and 2(d)) but because leaf canopy mass was decreased substantially, shaded plants had much thinner leaves. This evidently reflects a morphological compensation response, where decreased amounts of available photosynthate are prioritized to maximize photosynthetic surface. In past experiments by others, greater specific leaf area and leaf area ratio were observed under reduced light conditions with jimsonweed (Datura stramonium L.), velvetleaf (Abutilon theophrasti Medik.), and soybean [29]. Thinner leaves and a less dense canopy evidently are an important adaptation of 


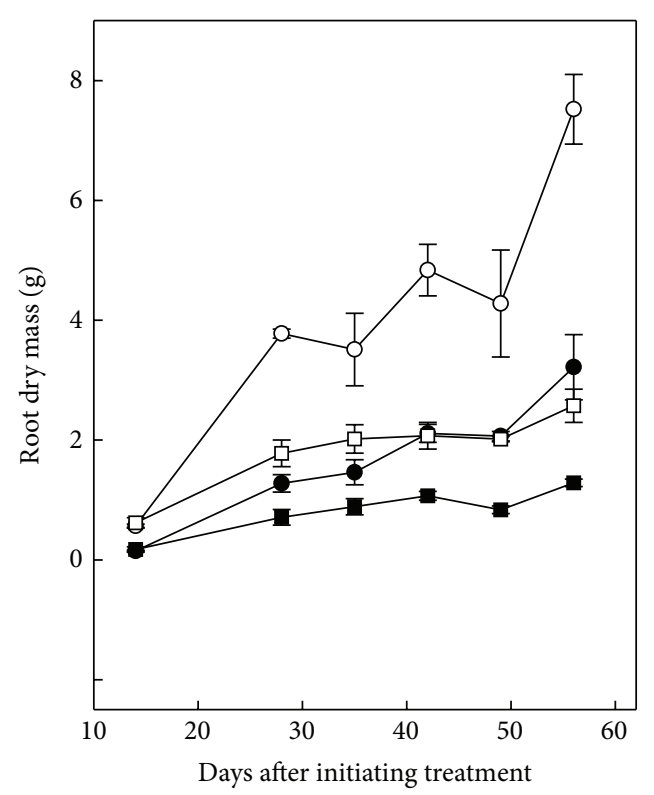

- High nutrition, full light

- High nutrition, reduced light

口 Low nutrition, full light

- Low nutrition, reduced light

(a)

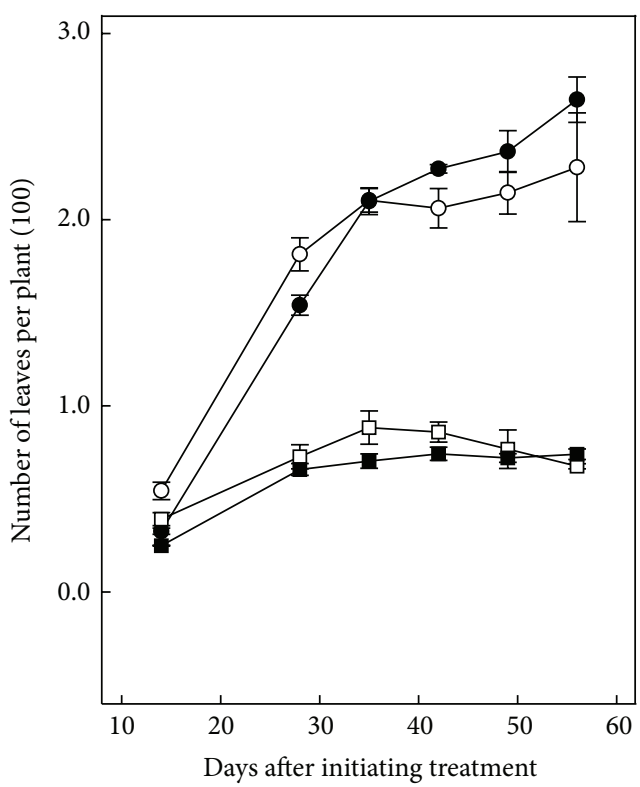

- High nutrition, full light

- High nutrition, reduced light

$\square$ Low nutrition, full light

- Low nutrition, reduced light

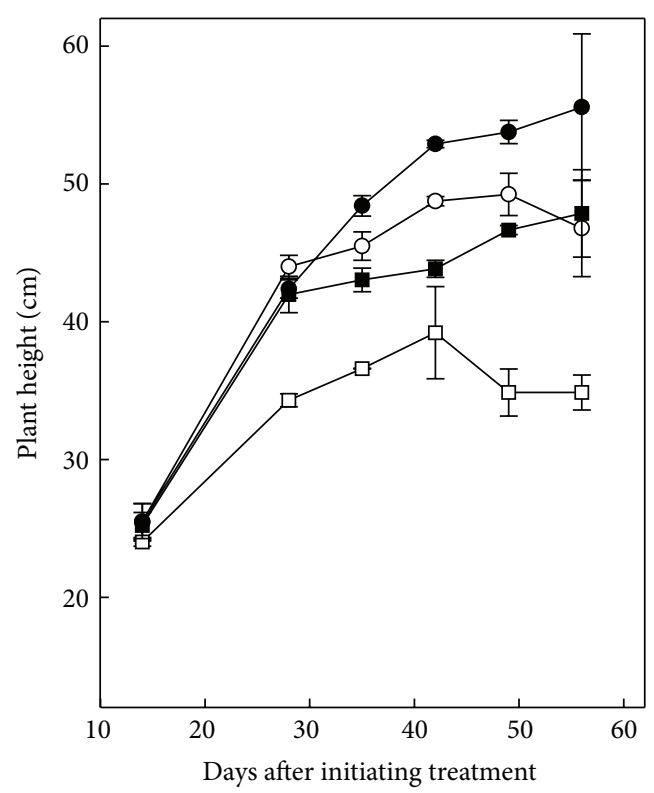

○ High nutrition, full light a Low nutrition, full light

- High nutrition, reduced light - Low nutrition, reduced light

(b)

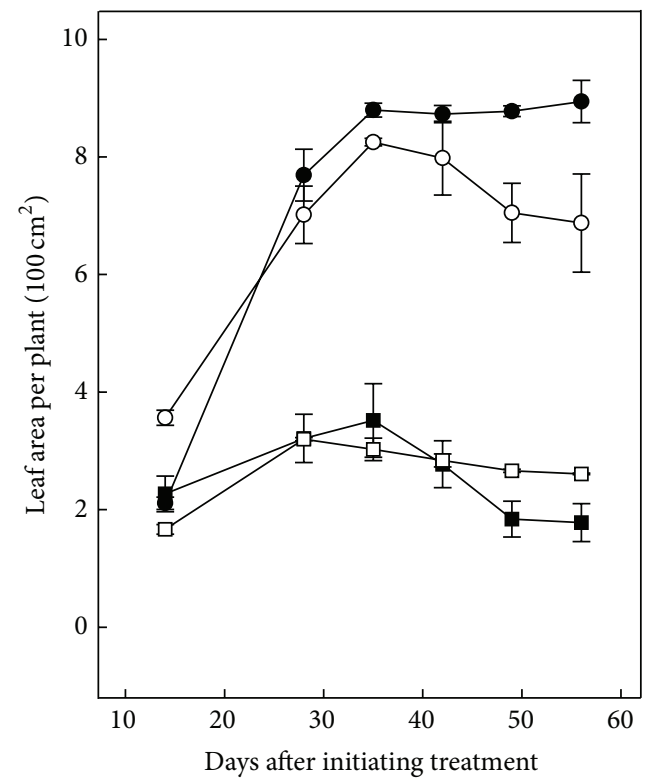

- High nutrition, full light

口 Low nutrition, full light

- High nutrition, reduced light

- Low nutrition, reduced light

FIGURE 2: Effects of nutrition level and light intensity on (a) root dry mass, (b) plant height, (c) number of leaves per plant, and (d) leaf area per plant of $C$. benghalensis. Data points are means of six replicates, and bars indicate standard errors of the mean.

plants growing under shaded conditions that permits light penetration to lower leaves [30,31].

As was the case with altered nutrition, shading had no impact on initiation of flowering (data not shown), but there were significant decreases in aerial spathe production (Table 1). Subterranean spathe production tended to be suppressed slightly by shading, but most of the observed differences were not statistically significant (Table 1).

The degrees of adjustment in spathe production above and below ground with plants that received low nutrition and those under shading indicate that $C$. benghalensis shifts to a "survival" strategy when resources are limited [32]. Even 
TABLE 1: Effects of nutrient supply and light on C. benghalensis aerial and subterranean spathe production.

\begin{tabular}{|c|c|c|c|c|c|c|c|c|c|c|c|}
\hline \multirow{2}{*}{\multicolumn{2}{|c|}{ Treatment }} & \multicolumn{5}{|c|}{ Aerial spathes } & \multicolumn{5}{|c|}{ Subterranean spathes } \\
\hline & & & & ter tre & & & & & fter $\mathrm{t}$ & & \\
\hline \multirow[t]{2}{*}{ Nutrient $^{\mathrm{a}}$} & Light $^{\mathrm{b}}$ & 28 & 35 & 42 & 49 & 56 & 28 & 35 & 42 & 49 & 56 \\
\hline & & \multicolumn{10}{|c|}{ Number of spathes plant $^{-1}$} \\
\hline High & Full & $132^{\mathrm{c}}$ & 251 & 286 & 379 & 558 & 16 & 23 & 34 & 55 & 80 \\
\hline High & Shade & 68 & 150 & 212 & 284 & 398 & 7 & 13 & 26 & 37 & 54 \\
\hline Low & Full & 65 & 115 & 126 & 124 & 150 & 11 & 20 & 30 & 35 & 52 \\
\hline Low & Shade & 38 & 66 & 92 & 90 & 124 & 5 & 13 & 22 & 29 & 41 \\
\hline \multicolumn{2}{|c|}{$\mathrm{HSD}_{0.05}{ }^{\mathrm{d}}$} & 81 & 56 & 61 & 75 & 35 & NS & NS & NS & NS & 30 \\
\hline
\end{tabular}

${ }^{a}$ Plants treated with high nutrient level received complete Hoagland's nutrient solution on a daily basis; plants treated with low nutrient level received complete Hoagland's nutrient solution once a week.

${ }^{\mathrm{b}}$ PPFD under full light was at $600 \mu \mathrm{mol} \mathrm{m}^{-2} \mathrm{~s}^{-1}$; PPFD under shade was at $324 \mu \mathrm{mol} \mathrm{m}^{-2} \mathrm{~s}^{-1}$.

${ }^{\mathrm{c}}$ Values are means of six replicates.

${ }^{\mathrm{d}}$ Tukey's honest significant difference at $\alpha=0.05$.

with severely reduced growth and restriction of aboveground spathe production, belowground reproduction tended to be maintained. On an individual plant basis, this increases the likelihood of genetic persistence, mainly because of less predation than occurs above ground. From an agronomic viewpoint, genetic persistence equates with a high likelihood of persistence in field soils. Difficulties with eradication of $C$. benghalensis in agricultural fields are clearly implied.

3.2. Response to Altered Photoperiod. Little has been published about $C$. benghalensis's photoperiod sensitivity, particularly in the high temperature range where its growth and potential interference with crops are the greatest. High temperature interactions with photoperiod are becoming more important with global warming, as extension of high temperatures into months with shorter photoperiods could result in growth and reproductive characteristics unlike those in summer months. These experiments were specifically designed (a) to examine whether flowering was photoperiod sensitive and (b) to determine the extent that vegetative growth and reproductive output were altered by short days. All of the photoperiod treatments were imposed with plants growing under high nutrition.

Flowering of $C$. benghalensis was altered in short days (Figure 3). With the shortened light period of 9 hours and at the high temperature of $35 / 28^{\circ} \mathrm{C}$, flowering occurred at day 27 whereas with long-day plants (with the night interruption) flowering occurred 3 days later at day 30 . With the 9-hour light period and $30 / 22^{\circ} \mathrm{C}$ temperature, the short-day plants flowered at day 33 compared to day 40 with the longday plants. Plants growing in the $30 / 30^{\circ} \mathrm{C}$ temperature also flowered sooner in short days, in this case on day 29, when compared to short-day plants at $30 / 26^{\circ} \mathrm{C}$. The difference in short-day and long-day flowering with $C$. benghalensis contrasts with the much stronger suppression of flowering in soybean (Glycine max L.) and tobacco (Nicotiana tabacum L.) under similar conditions with a night interruption $[33,34]$.

Even though short-day plants flowered only a few days earlier than long-day plants, whole plant growth was greatly reduced for plants exposed to short days (Figure 4). As might have been predicted from earlier studies examining $C$.

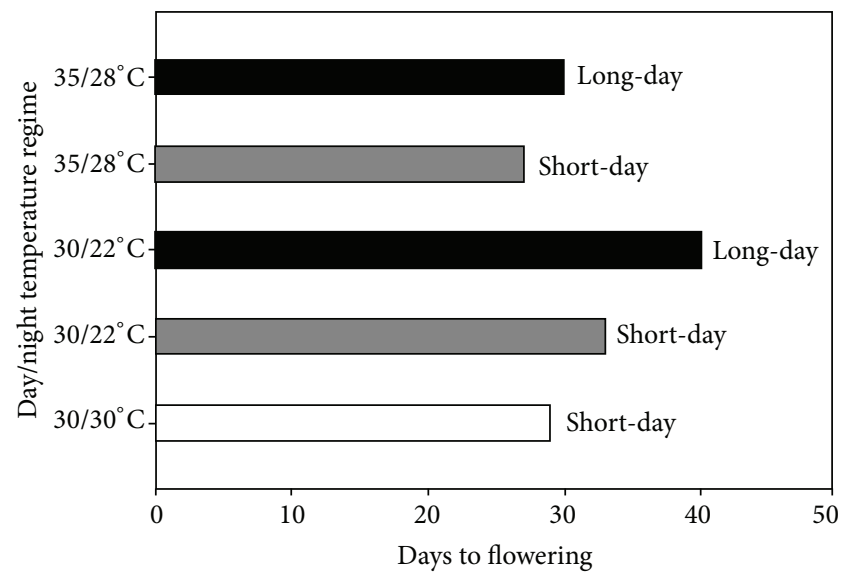

Figure 3: Photoperiod effects on time of flowering of C. benghalensis plants. Long-day plants (LD) were exposed to a $9 \mathrm{~h}$ light period and a $3 \mathrm{~h}$ night interruption with nonphotosynthetic light to suppress flowering. Short-day plants (SD) were exposed only to the $9 \mathrm{~h}$ light period.

benghalensis response to high temperature $[17,35]$, growth processes were enhanced at the high $35 / 28^{\circ} \mathrm{C}$ temperature. However, mass of short-day plants, when compared to longday plants, was decreased by about $40 \%$ at $56 \mathrm{~d}$ in $35 / 28^{\circ} \mathrm{C}$ and growth was decreased $60 \%$ by short days in the slower growing plants at $30 / 22^{\circ} \mathrm{C}$. The decreases in plant mass were accompanied by decreases in root mass (Figure 5(a)), plant height (Figure 5(b)), and total leaf area (Figure 5(d)) compared to plants in the long-day photoperiod. Effects on the number of leaves were not as consistent, with reductions in leaf number occurring in short-day plants at $30 / 22^{\circ} \mathrm{C}$ but not at $35 / 28^{\circ} \mathrm{C}$ by the final 56 -day harvest (Figure $5(\mathrm{c})$ ). Taken as a whole, our results are at odds with a previous study where it was concluded that photoperiod would not greatly affect growth of C. benghalensis [36].

Reproductive performance in the short-day plants was statistically similar to that in the long-day plants at in $35 / 28^{\circ} \mathrm{C}$ and $30 / 22^{\circ} \mathrm{C}$ temperatures. Thus, reproductive data for the short- and long-day plants were combined (Table 2). 
TABLE 2: Effects of three temperature regimes on C. benghalensis aerial and subterranean spathe production. Data for the photoperiod treatments were similar, statistically, so they were combined.

\begin{tabular}{|c|c|c|c|c|c|c|}
\hline \multirow{3}{*}{ Temperature regime } & \multicolumn{3}{|c|}{ Aerial spathes } & \multicolumn{3}{|c|}{ Subterranean spathes } \\
\hline & \multicolumn{3}{|c|}{ Days after treatment } & \multicolumn{3}{|c|}{ Days after treatment } \\
\hline & 28 & 42 & 56 & 28 & 42 & 56 \\
\hline${ }^{\circ} \mathrm{C}$ & \multicolumn{6}{|c|}{ Number of spathes plant ${ }^{-1}$} \\
\hline $35 / 28^{\mathrm{a}}$ & $18^{\mathrm{b}}$ & 68 & 87 & 4 & 30 & 31 \\
\hline $30 / 22$ & 22 & 94 & 120 & 1 & 15 & 22 \\
\hline $30 / 30$ & 42 & 84 & 98 & 5 & 25 & 37 \\
\hline $\mathrm{HSD}_{0.05}{ }^{\mathrm{c}}$ & 4 & 15 & 20 & 1 & 5 & 5 \\
\hline
\end{tabular}

${ }^{\mathrm{a}}$ Numbers indicate day/night temperatures.

${ }^{\mathrm{b}}$ Values are means of 24 replicates. Photoperiod effects were nonsignificant at the $35 / 28$ and $30 / 22^{\circ} \mathrm{C}$ temperatures, so data were pooled for each temperature regime.

${ }^{c}$ Tukey's honest significant difference at $\alpha=0.05$.

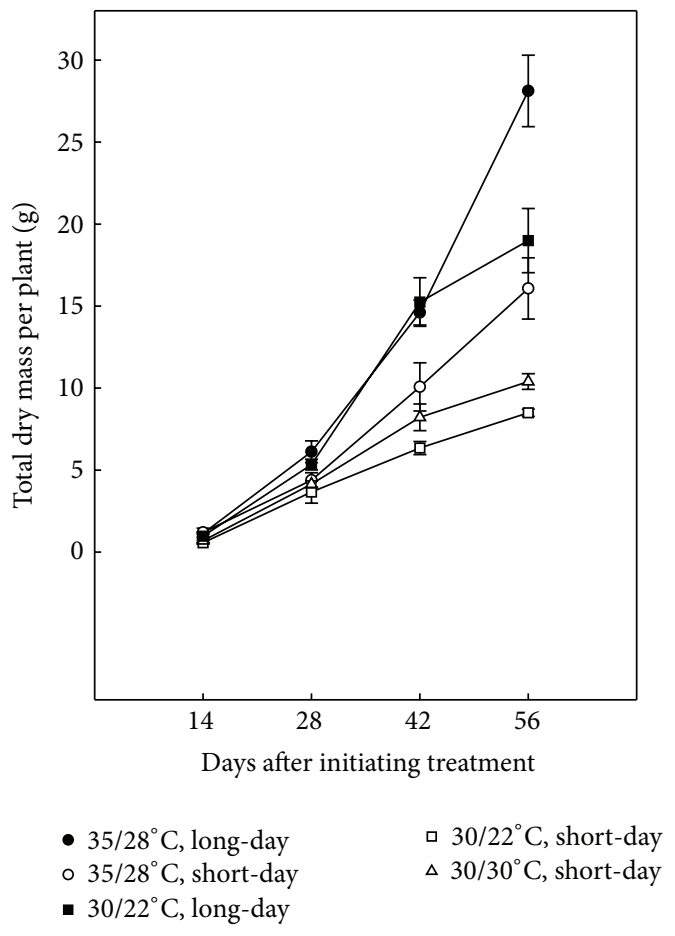

FIGURE 4: Effects of day/night temperature regime and altered photoperiod on total dry mass of C. benghalensis. The long-day treatment was imposed by a $3 \mathrm{~h}$ nonphotosynthetic night interruption in the middle of dark periods. LD: long-day; SD: short-day. Data points are means of six replicates, and bars indicate standard errors of the mean.

Some differences in the number of reproductive structures occurred among temperatures. At the higher temperature of $35 / 28^{\circ} \mathrm{C}$, the higher vegetative mass (Figure 4 ) was associated with lower production of aerial spathes and greater production of belowground spathes.

As indicated above with low fertility or shaded plants, it is quite evident that $C$. benghalensis retains an ability to sustain a high level of reproductive output in high temperature ranges, in this case even when whole plant growth is constrained by the physiological response to a shorter photoperiod. This resilience in reproduction is obviously of concern when it is considered that one of the biggest challenges in weed management is to limit seed production in agronomic fields, reducing the long-term soil seed bank. Studies have shown that as many as 8,000 to 12,000 seeds $\mathrm{m}^{-2}$ can be produced by $C$. benghalensis [7], and the seeds can remain viable for at least 3 to 4 years [13].

\section{Conclusions}

Much is unknown about how the invasive weed C. benghalensis interacts with the environment. These experiments with different nutrition, low light, and photoperiod treatments offer new insights into environmental factors that enhance or suppress the invasiveness of $C$. benghalensis in agricultural systems. One insight is that $C$. benghalensis competitiveness and reproduction are strongly increased by the high nutrition typically used with grain crops. A valid containment strategy with large infestations of $C$. benghalensis would be to grow a series of crops with low or no added nitrogen fertilizer, like soybean or an $\mathrm{N}_{2}$-fixing pasture. It should be emphasized that substantial growth and especially reproductive output still occurred at lower nutrition in our experiments, so it is anticipated that a degree of weed pressure will persist.

A second insight is that vegetative growth is suppressed under short days, even when flowering shifts only a few days. Thus, $C$. benghalensis competitiveness is likely to be reduced when germination and growth occur during shorter photoperiods outside of normal crop growing seasons, even though high temperatures may become more prevalent. A third important observation is that, regardless of the type of environment it faces, $C$. benghalensis exhibits a substantial reproductive capability, and this is true even when vegetative growth is suppressed by nutrition, low light, or a photoperiod shift. Underground reproduction appears to be particularly resilient. The persistent reproductive output underscores the importance of intensive management strategies to prevent introduction of $C$. benghalensis into agricultural fields. 


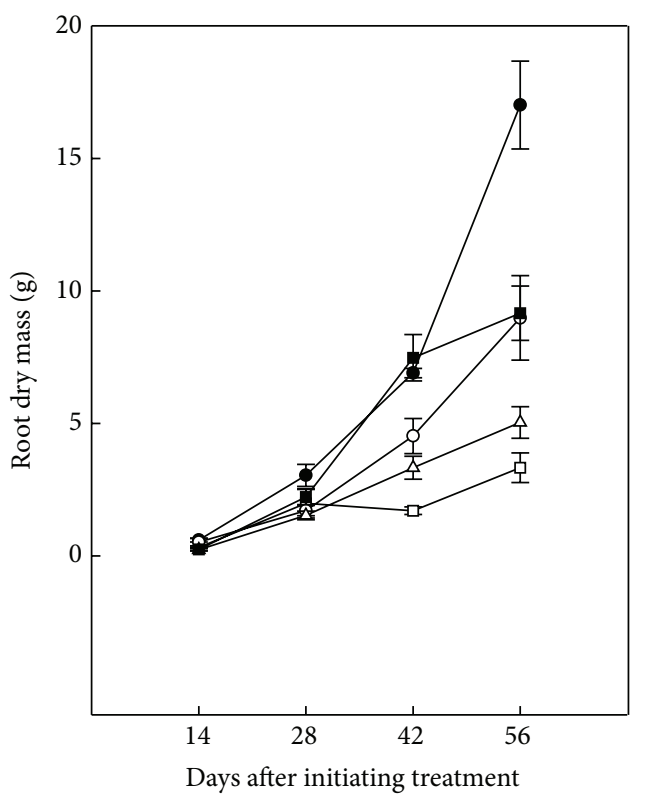

- $35 / 28^{\circ} \mathrm{C}$, long-day - $35 / 28^{\circ} \mathrm{C}$, short-day - $30 / 22^{\circ} \mathrm{C}$, long-day

(a)

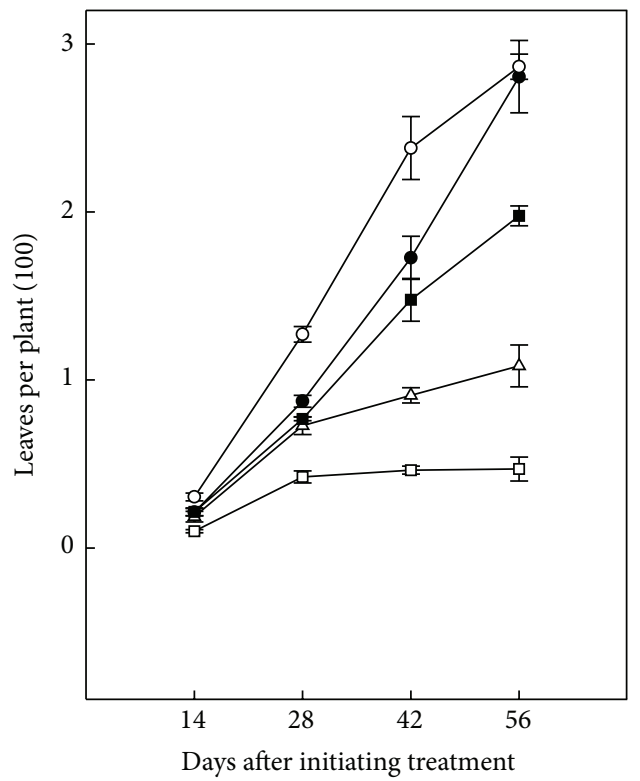

- $35 / 28^{\circ} \mathrm{C}$, long-day - $35 / 28^{\circ} \mathrm{C}$, short-day

- $30 / 22^{\circ} \mathrm{C}$, long-day

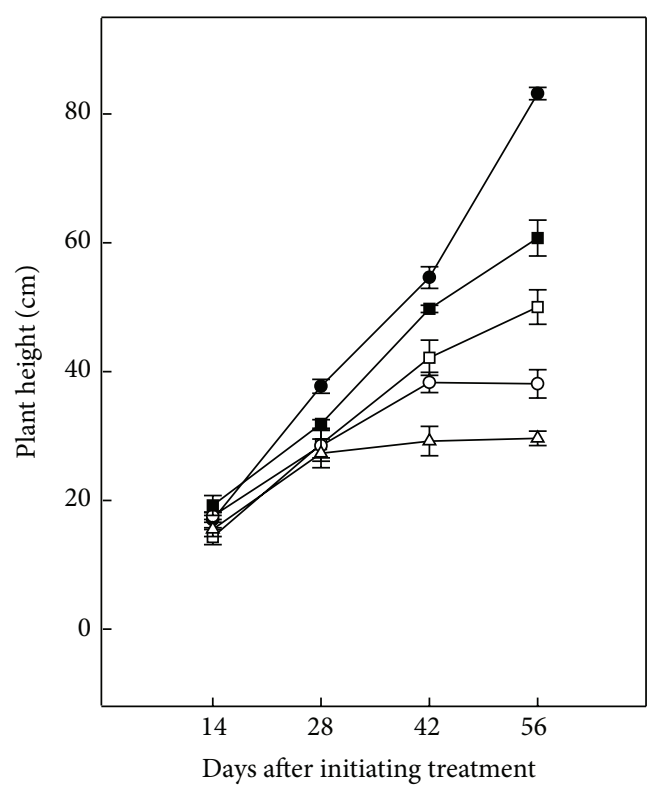

- $35 / 28^{\circ} \mathrm{C}$, long-day

- $35 / 28^{\circ} \mathrm{C}$, short-day

- $30 / 22^{\circ} \mathrm{C}$, short-day

$\triangle 30 / 30^{\circ} \mathrm{C}$, short-day

- $30 / 22^{\circ} \mathrm{C}$, long-day

(b)

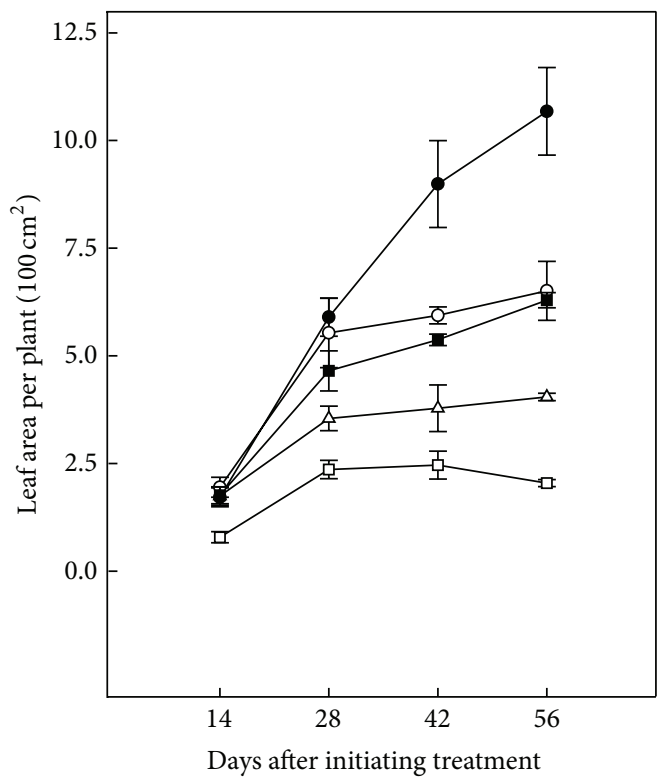

- $35 / 28^{\circ} \mathrm{C}$, long-day

- $35 / 28^{\circ} \mathrm{C}$, short-day

a $30 / 22^{\circ} \mathrm{C}$, short-day

$\triangle 30 / 30^{\circ} \mathrm{C}$, short-day

- $30 / 22^{\circ} \mathrm{C}$, long-day

(c)

(d)

FIGURE 5: Effects of day/night temperature regime and altered photoperiod on (a) root dry mass, (b) plant height, (c) number of leaves per plant, and (d) leaf area per plant of $C$. benghalensis. The long-day treatment was imposed by a $3 \mathrm{~h}$ nonphotosynthetic night interruption in the middle of dark periods. LD: long-day; SD: short-day. Data points are means of six replicates, and bars indicate standard errors. 


\section{Conflict of Interests}

The authors declare that there is no conflict of interests regarding the publication of this paper.

\section{Acknowledgments}

This research was funded by the US Department of Agriculture-Cooperative State Research, Education, and Extension Service-National Research Initiative (USDACSREES-NRI, Grant no. 2008-35320-18689) Program. The authors express appreciation to NCSU Phytotron staff for their help. Thanks are also due to Shannon Sermons and Laura Vance for constructive suggestions on the paper.

\section{References}

[1] R. B. Faden, "The misconstrued and rare species of Commelina (Commelinaceae) in the eastern United States," Annals of the Missouri Botanical Garden, vol. 80, no. 1, pp. 208-218, 1993.

[2] T. M. Webster and L. M. Sosnoskie, "Loss of glyphosate efficacy: a changing weed spectrum in Georgia cotton," Weed Science, vol. 58, no. 1, pp. 73-79, 2010.

[3] T. M. Webster, W. H. Faircloth, J. T. Flanders, E. P. Prostko, and T. L. Grey, "The critical period of Bengal dayflower (Commelina bengalensis) control in peanut," Weed Science, vol. 55, no. 4, pp. 359-364, 2007.

[4] T. M. Webster, T. L. Grey, J. T. Flanders, and A. S. Culpepper, "Cotton planting date affects the critical period of Benghal dayflower (Commelina benghalensis) control," Weed Science, vol. 57, no. 1, pp. 81-86, 2009.

[5] T. M. Webster, M. G. Burton, A. S. Culpepper, A. C. York, and E. P. Prostko, "Tropical spiderwort (Commelina benghalensis): a tropical invader threatens agroecosystems of the Southern United States," Weed Technology, vol. 19, no. 3, pp. 501-508, 2005.

[6] L. G. Holm, D. L. Plucknett, J. V. Pancho, and J. P. Herberger, The World's Worst Weeds: Distribution and Biology, University Press of Hawaii, Honolulu, Hawaii, USA, 1977.

[7] S. R. Walker and J. P. Evenson, "Biology of Commelina benghalensis L. in south-eastern Queensland. 1. Growth, development and seed production," Weed Research, vol. 25, no. 4, pp. 239-244, 1985.

[8] P. Maheshwari and J. K. Maheshwari, "Floral dimorphism in Commelina forskalaei Vahl. and Benghal dayflower L.," Phytomorphology, vol. 5, pp. 413-422, 1955.

[9] S. Y. Kim, S. K. De Datta, and B. L. Mercado, "The effect of chemical and heat treatments on germination of Commelina benghalensis L. aerial seeds," Weed Research, vol. 30, no. 2, pp. 109-116, 1990.

[10] S. R. Walker and J. P. Evenson, "Biology of Commelina benghalensis L. in South-eastern Queensland. 2. Seed dormancy, germination and emergence," Weed Research, vol. 25, no. 4, pp. 245-250, 1985.

[11] G. D. Budd, P. E. L. Thomas, and J. C. S. Allison, "Vegetative regeneration, depth of germination and seed dormancy in Commelina benghalensis L.," Rhodesian Journal of Agricultural Research, vol. 17, no. 2, pp. 151-153, 1979.

[12] A. S. Culpepper, J. T. Flanders, A. C. York, and T. M. Webster, "Tropical spiderwort (Commelina benghalensis) control in glyphosate-resistant cotton (Gossypium hirsutum)," Weed Technology, vol. 18, pp. 432-436, 2004.
[13] M. K. Riar, T. M. Webster, B. J. Brecke et al., "Benghal dayflower (Commelina benghalensis) seed viability in soil," Weed Science, vol. 60, no. 4, pp. 589-592, 2012.

[14] M. K. Riar, J. F. Spears, J. C. Burns, D. L. Jordan, C. Zhang, and T. W. Rufty, "Persistence of Benghal dayflower (Commelina benghalensis) in sustainable agronomic systems: potential impacts of hay bale storage, animal digestion, and cultivation," Agroecology and Sustainable Food Systems, vol. 38, no. 3, pp. 283-298, 2014.

[15] J. Hansen, Storms of My Grandchildren, Bloomsbury Publishing, New York, NY, USA, 2009.

[16] J. Hansen, M. Sato, G. Russell, and P. Kharecha, "Climate sensitivity, sea level and atmospheric carbon dioxide," Philosophical Transactions of the Royal Society A, vol. 371, no. 2001, Article ID 20120294, 2013.

[17] S. M. Sermons, M. G. Burton, and T. W. Rufty, “Temperature response of Benghal dayflower (Commelina benghalensis): implications for geographic range," Weed Science, vol. 56, no. 5, pp. 707-713, 2008.

[18] R. H. Goddard, T. M. Webster, R. Carter, and T. L. Grey, "Resistance of Benghal dayflower (Commelina benghalensis) seeds to harsh environments and the implications for dispersal by mourning Doves (Zenaida macroura) in Georgia, U.S.A," Weed Science, vol. 57, no. 6, pp. 603-612, 2009.

[19] C. H. Saravitz, R. J. Downs, and J. F. Thomas, "Phytotron procedural manual for controlled-environment research at the Southeastern Plant Environment Laboratory," Technical Bulletin 244 (Revised), North Carolina State University, North Carolina Agricultural Research Service, Raleigh, NC, USA, 2009.

[20] J. Hanke, K. M. Hartmann, and H. Mohr, "The effects of night breaks on flowering of Sinapis alba L.," Planta, vol. 86, no. 3, pp. 235-249, 1969.

[21] F. S. Chapin, "Integrated responses of plants to stress," BioScience, vol. 41, no. 1, pp. 29-36, 1991.

[22] T. W. Rufty, "Probing the carbon and nitrogen interaction: a whole plant perspective," in A Molecular Approach to Primary Metabolism in Higher Plants, C. H. Foyer and P. Quick, Eds., pp. 255-273, Taylor \& Francis, London, UK, 1997.

[23] S. W. Buol, R. J. Southard, R. C. Graham, and P. A. McDaniel, Soil Genesis and Classification, Wiley-Blackwell, London, UK, 6th edition, 2011.

[24] J. Maillet and C. Lopez-Garcia, "What criteria are relevant for predicting the invasive capacity of a new agricultural weed? The case of invasive American species in France," Weed Research, vol. 40, no. 1, pp. 11-26, 2000.

[25] A. Kolb and P. Alpert, "Effects of nitrogen and salinity on growth and competition between a native grass and an invasive congener," Biological Invasions, vol. 5, no. 3, pp. 229-238, 2003.

[26] J. H. Burns, "A comparison of invasive and non-invasive dayflowers (Commelinaceae) across experimental nutrient and water gradients," Diversity and Distributions, vol. 10, no. 5-6, pp. 387-397, 2004.

[27] J. H. Burns and A. A. Winn, "A comparison of plastic responses to competition by invasive and non-invasive congeners in the Commelinaceae," Biological Invasions, vol. 8, no. 4, pp. 797-807, 2006.

[28] K. A. Moyer-Henry, J. W. Burton, D. W. Israel, and T. W. Rufty, "Nitrogen transfer between plants: a ${ }^{15} \mathrm{~N}$ natural abundance study with crop and weed species," Plant and Soil, vol. 282, no. 1-2, pp. 7-20, 2006. 
[29] E. E. Regnier, M. E. Salvucci, and E. W. Stoller, "Photosynthesis and growth responses to irradiance in soybean (Glycine max) and three broadleaf weeds," Weed Science, vol. 36, no. 4, pp. 487496, 2008.

[30] O. Björkman, "Responses to different quantum flux densities," in Physiological Plant Ecology I, O. L. Lange, P. S. Nobel, C. B. Osmond, and H. Ziegler, Eds., vol. 12/A of Encyclopedia of Plant Physiology, pp. 57-107, Springer, Berlin, Germany, 1981.

[31] E. W. Stoller and T. W. Myers, "Response of soybeans (Glycine max) and four broadleaf weeds to reduced irradiance," Weed Science, vol. 37, no. 4, pp. 570-574, 1989.

[32] G. P. Cheplick and J. A. Quinn, "Amphicarpum purshii and the 'pessimistic strategy' in amphicarpic annuals with subterranean fruit," Oecologia, vol. 52, no. 3, pp. 327-332, 1982.

[33] J. F. Thomas, C. E. Anderson, C. D. Jr. Raper, and R. J. Downs, "Time of floral initiation in tobacco as a function of temperature and photoperiod," Canadian Journal of Botany, vol. 53, no. 14, pp. 1400-1410, 1975.

[34] J. F. Thomas and C. D. Raper, "Morphological response of soybeans as governed by photoperiod, temperature, and age at treatment," Botanical Gazette, vol. 138, no. 3, pp. 321-328, 1977.

[35] M. H. Sabila, T. L. Grey, T. M. Webster, W. K. Vencill, and D. G. Shilling, "Evaluation of factors that influence benghal dayflower (Commelina benghalensis) seed germination and emergence," Weed Science, vol. 60, no. 1, pp. 75-80, 2012.

[36] C. B. Gonzalez and C. R. B. Haddad, "Light and temperature effects on flowering and seed germination of Commelina benghalensis L.", Archives of Biological Tecnology, vol. 38, pp. 651-659, 1995. 


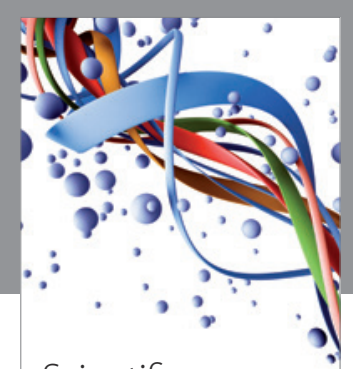

Scientifica
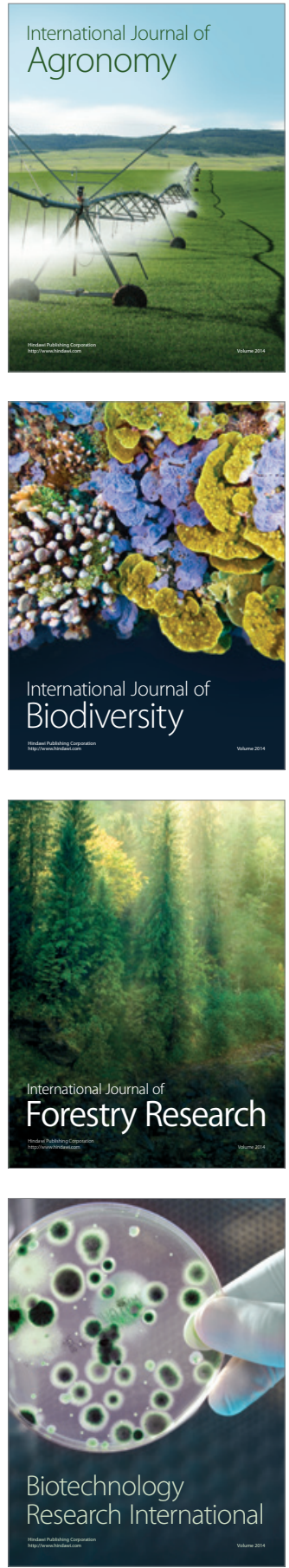
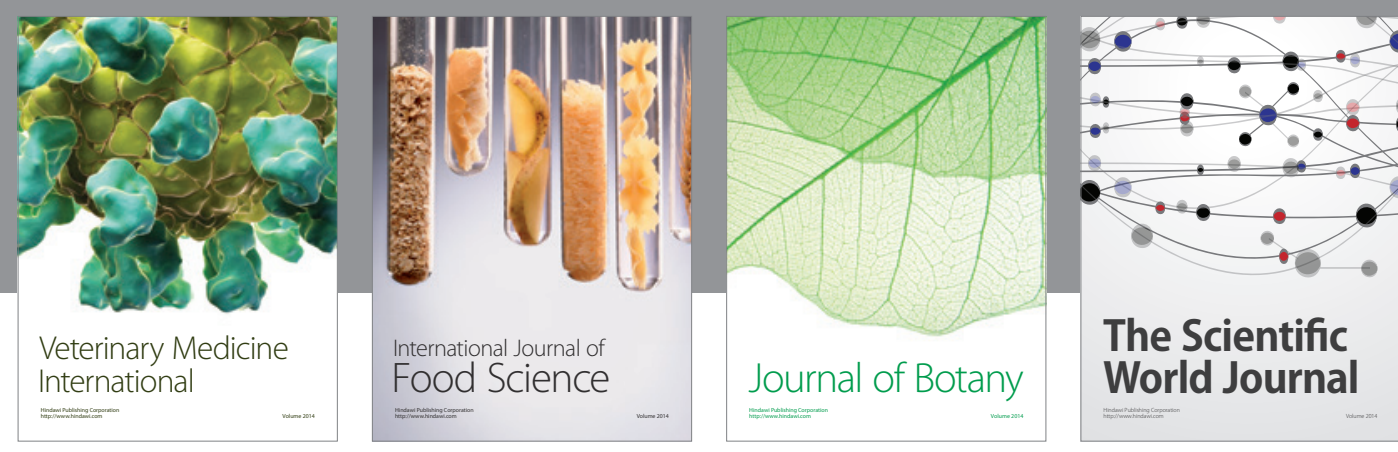

The Scientific

\section{World Journal}

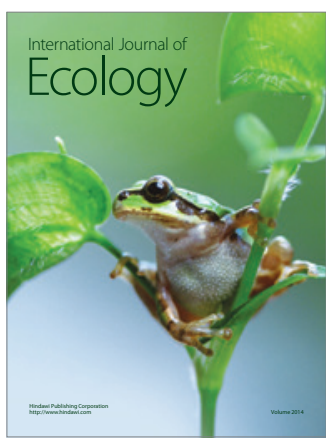

\section{Hindawi}

Submit your manuscripts at

http://www.hindawi.com
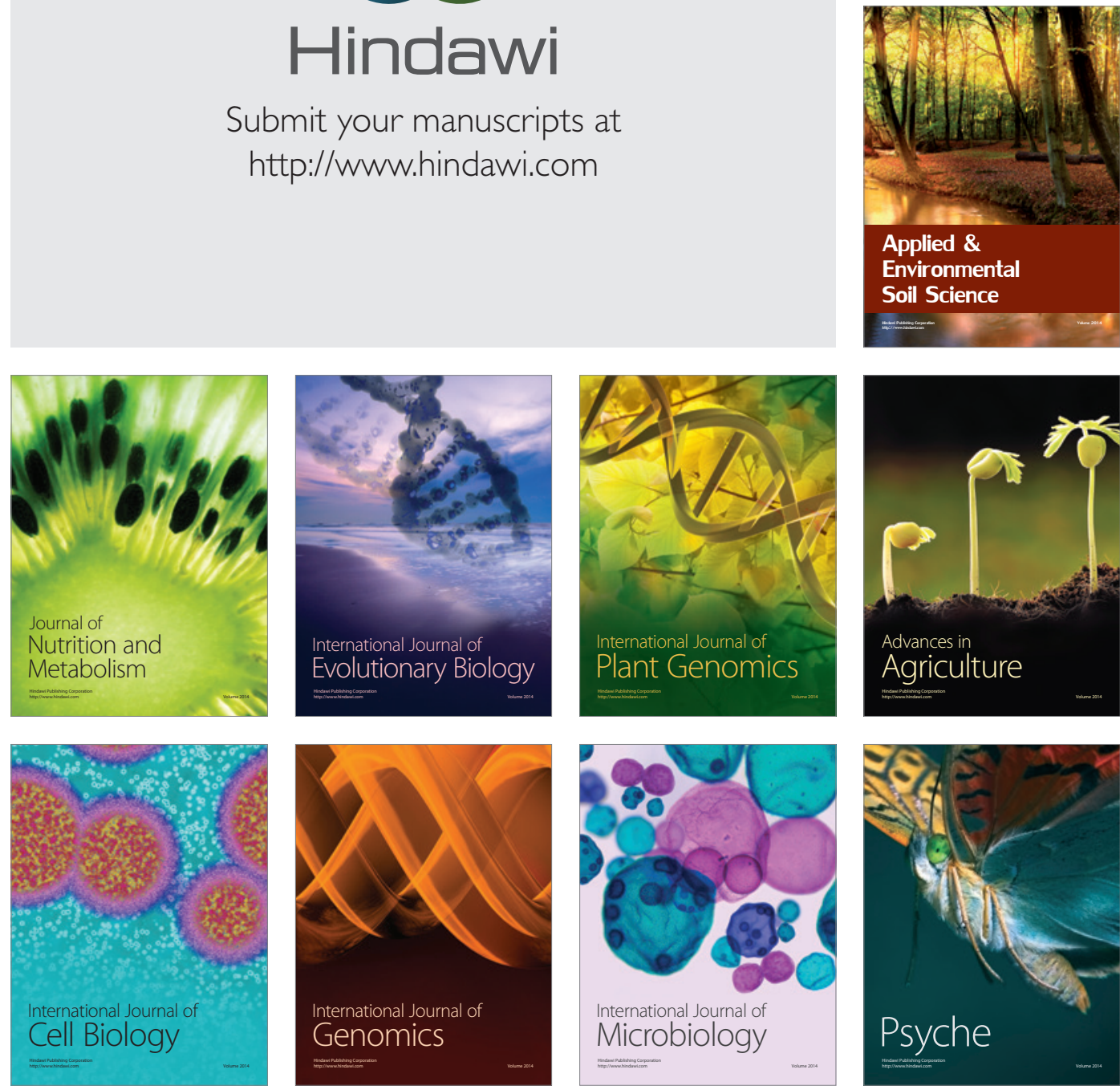
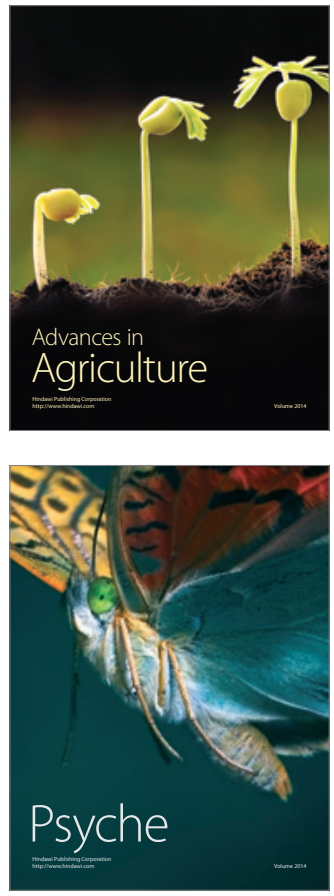